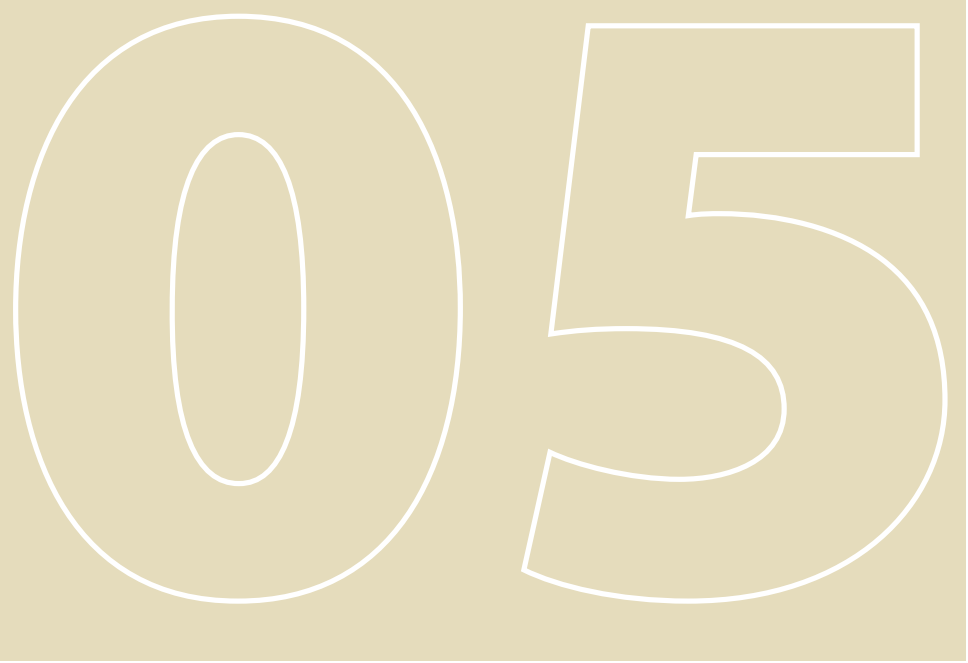

\section{GOD'S MAIDSERVANTS:}

\section{A PENTECOSTAL WOMEN} (COUNTER)NARRATIVE*

Siervas de Dios: una (contra)narrativa de mujeres pentecostales

* This article is part of a more comprehensive research into the relationship between women's movements, feminisms, and Protestantism, that resulted in my Master Thesis. I would like to thank my supervisors, professor Gilberta Golinelli at the University of Bologna and professor María Espinosa Spínola at the University of Granada, both part of GEMMA - Master Erasmus Mundus in Gender and Women's Studies, for all their guidance, support, and counselling during my research journey. I am also thankful to the IDMJI in Milan and its parishioners, for helping me understand the tenets of their faith. Without their cooperation, this research would not have been possible.

\section{VALENTINA CORAL GÓMEZ}

\section{Dipartimento di Lingue, Letterature e Culture}

Moderne - LILEC

Alma Mater Studiorum - Università di Bologna

Fecha de recepción: 9 de abril de 2020 Fecha de aceptación: 21 de julio de 2020

\section{ABSTRACT}

By claiming that women and men can both hear God's call and can both serve God in the same capacities, some Pentecostal and Neo-Pentecostal churches seem to give women a new sense of self-worth and empowerment. An analysis of the IDMJI, a Neo-Pentecostal Church established in Colombia, and its political party, MIRA, allowed me not only to appreciate how this process of empowerment works but also to observe how these religious groups, more often than not, keep intact several gender stereotypes that can be detrimental to their own parishioners and to society at large. The IDMJI is led by a woman who claims that both men and women can preach. Its political party have acted in the past on behalf of women and other minorities, asking for parity in public office and protesting against gender and domestic violence. Nevertheless, the value they give to women is still highly related to their role as wives and mothers, and they exclude the possibility of sexual or affective relations that do not conform to the heterosexual norm. Thus, they continue reinforcing patriarchal values and jeopardizing the self-determination of women as well as the rights of the members of the LGBTQ+ communities.

\section{Keywords}

Empowerment, Pentecostalism, Christianity, Women's Rights, LGBTQ+ Rights. 


\section{RESUMEN}

Basándose en la doctrina de que tanto las mujeres como los hombres pueden sentir el llamado de Dios y, de consecuencia, servirle de la misma manera, algunas iglesias pentecostales y neo-pentecostales parecen favorecer el empoderamiento de las mujeres. Un análisis de la IDMJI, una iglesia neo-pentecostal fundada en Colombia, y de su correspondiente partido político, MIRA, permite apreciar cómo opera este empoderamiento, evidenciando al mismo tiempo cómo estos grupos religiosos mantienen intactos estereotipos de género que pueden perjudicar tanto a sus propios feligreses como a la sociedad en general. La IDMJ es liderada por una mujer y sostiene que tanto hombres como mujeres pueden predicar. Su partido político ha realizado acciones en favor de las mujeres y otras minorías, por ejemplo, exigiendo la paridad en el servicio público y protestando en contra de la violencia de género. No obstante, el valor que le dan a las mujeres sigue estando altamente relacionado con su papel de esposas y madres. Además, no contemplan la posibilidad de relaciones afectivas o sexuales que no se ajusten al modelo heteronormativo. De esta manera, refuerzan el modelo social patriarcal y ponen en riesgo tanto la autodeterminación de las mujeres

\section{Palabras clave}

Empoderamiento, pentecostalismo, cristianismo, derechos de las mujeres, derechos de la comunidad LGBTQ+.

It seems that the common position in academia and activism is that religions and feminisms are incompatible. Within Christianity, the vast majority of groups, whether they are affiliated to the Roman Catholic Church or to the different denominations associated with Protestantism, are seen mainly as structures that maintain and reinforce patriarchal cultures, perpetuating gender stereotypes that keep women in the position of the subjugated other and negate any and all gender and sexual manifestations that do not correspond with the heteronormative ideal.

When it comes to new forms of Christianity in Latin America, i.e., Evangelicals and Pentecostals, they are seen mainly as the source of counter-movements that go against the rights of women and LGBTQ+ communities. Those counter-movements affiliated to conservative Christian groups have spread throughout the region fighting against what they identify as gender ideology, which manifests itself, according to them, through the approval of same-sex marriage and adoption by members of the LGBTQ+ communities, mandatory sex education at school, and decriminalization of abortion, among others.

\section{INTRODUCTION}

1. «Marchas en el país contra Mineducación por revisión de manuales de convivencia de colegios». El Espectador, August 10th, 2016. Available at: https:// www.elespectador.com/noticias/ educacion/marchas-el-pais-contramineducacion-revision-de-manualearticulo-648339

«Así fue la marcha contra supuestos cambios en manuales de convivencia». El Tiempo, August 10th, 2016. Available at: https://www.eltiempo.com/colombia/ otras-ciudades/protestas-contracartillas-de-ideologia-de-genero-encolegios-42293

2. «El rol de las iglesias cristianas evangélicas en la victoria del "No" en el plebiscito». W Radio, October 5th, 2016. Available at: http://www.wradio.com.co/ noticias/actualidad/el-rol-de-las-iglesiascristianas-evangelicas-en-la-victoriadel-no-en-el-plebiscito/20161005/ nota/3265407.aspx 
In Colombia these counter-movements have had three major manifestations in recent years: 1) the protests against the new guidelines regarding sex education dictated by the Ministry of Education in 2016, which were accused of promoting gender ideology; ${ }^{1}$ 2) the opposition -almost concomitant with the aforementioned protests-, of several Evangelical and Pentecostal churches against the peace agreements between the Colombian government and the Farc guerrillas for considering them, once again, contaminated by gender ideology and an attack on the traditional family model; ${ }^{2}$ and 3) the Popular Referendum promoted by a known Christian congresswoman that attempted to change the Political Constitution in order to allow adoption only to heterosexual couples. ${ }^{3}$ The first two instances had devastating effects: the peace referendum was lost by a close margin, and considering the $50.2 \%$ of the people who voted against the peace agreements, it is estimated that at least two million were Evangelicals. Moreover, they also caused the resignation of the Minister of Education, who happened to be an openly lesbian woman. ${ }^{4}$ In the third case, although it never came to happen because the House of Representative rejected the project during its third debate; ${ }^{5}$ it is significant that more than two million Colombians supported the call for a Constitutional Referendum that would have irrevocably mined the rights of the LGBTQ+ community.

According to William Mauricio Beltrán (2013), by 201216.7 \% of Colombia's population was Protestant or Evangelical. Both the research made by David Stoll (1990) and the studies carried out by Steve Brouwer, Paul Gifford and Susan D. Rose (1996), concluded that the majority of Protestants in Latin America are Pentecostals. This assertion also applies to Colombia where, as stated by Beltrán, «Protestantism is predominantly Pentecostal» (2013: 99). Women seem to be particularly attracted to these new religious groups, and in some cases they are the first to convert (Stoll, 1990; Brusco, 1995; Beltrán, 2013). Understanding why so many women are attracted to these religious groups despite their (apparent) regressive nature, apart from society's common misconceptions of religious alienation, ignorance and blind submission, is an important tool for contemporary feminist movements and their struggle against conservative counter-movements.

My interest in what are commonly known in Colombia as Christian Churches, an umbrella term that covers different denominations of Protestant churches, started as personal curiosity. Although raised in a predominantly passive Catholic environment, there was always someone close that was affiliated to or even an active member of a Christian Church. This meant attending from time to time to some Christian religious service, listening to
Marcos, Ana. «El voto evangélico, clave en la victoria del 'no' en el plebiscito de Colombia». El País, October 12th, 2016. Available at: https://elpais. com/internacional/2016/10/12/ colombia/1476237985_601462.html. Last accessed September 6, 2018

3. Jiménez Valencia, Sebastián y Bravo Medina, Paula. «Recogen 2 millones de firmas para referendo contra adopción por parte de parejas gay». CNN en Español, March 29th, 2016. Available at: https:// cnnespanol.cnn.com/2016/03/29/masde-2-millones-de-colombianos-firmaroncontra-la-adopcion-gay/; «Radican firmas en Registraduría para respaldar referendo contra adopción gay». Noticias Caracol, March 29th, 2016. Available at: https:// noticias.caracoltv.com/colombia/radicanfirmas-en-registraduria-para-respaldarreferendo-contra-adopcion-gay

4. «Razones de la renuncia de Gina Parody». Caracol Radio, October 4, 2016. Available at: https:// caracol.com.co/radio/2016/10/04/ nacional/1475595791_414735.html

5. «Se hundió referendo de Viviane Morales, el No ganó en tercer debate». El Espectador, May 10th, 2017. Available at: https://www.elespectador.com/noticias/ politica/se-hundio-referendo-de-vivianemorales-el-no-gano-en-tercer-debatearticulo-693218

«El intenso debate que hundió el referendo antiadopción gay». El Tiempo, May 11th, 2017. Available at: https:// www.eltiempo.com/politica/congreso/ se-hunde-proyecto-para-convocarreferendo-que-impedia-adopciongay-86736

6. The original is in Spanish. «el protestantismo colombiano es predominantemente Pentecostal». This and any other translation of this material, unless stated otherwise, is mine.

HOW A PERSONAL INTEREST BECAME ACADEMIC RESEARCH 
the odd bible study, and even receiving books about biblical stories. This particular way of (non)belonging gave me a glimpse of a world that I found fascinating because it was new and partially unknown, but the more I grew up, the more I found it oppressive.

In the course of my job in Bogotás City Council, I met different members, mainly women, of Iglesia de Dios Ministerial de Jesucristo Internacional (IDMJI) and its political party, MIRA (Movimiento Independiente de Renovación Absoluta). They puzzled me in several ways. They identify themselves as neo-Pentecostals, but their religious leader is a woman: María Luisa Piraquive de Moreno. Although Piraquive has not been free from scandal, both in and outside the Church, the fact that she has so much power inside a Christian religious organization deserves special attention. The fact that the Party tends to use the zipper system to set up their electoral lists, which grants and guarantees equal participation for men and women, should also be considered. In the past, their councilwoman was the coordinator of the unofficial ${ }^{8}$ women's group at the City Council. The Party presented and supported bills in favour of women's rights (like one asking for parity in public office) and made several campaigns against gender and domestic violence. The members of the Party, at least during my time working in the City Council, never preached or tried to evangelize either me or, to my knowledge, other staff members of the City Council. In the debates about the different bills, the Party's Councillors they never brought to the forefront religious arguments in order to argue in favour or against any particular project.

This experience inspired me to inquire about the relation between women and religion. Thus, I focused my research on unveiling and understanding the connections between women's movements and Protestantism, identifying whether and how there could be a positive interaction among them. The present article is a partial result of that larger investigation where I analysed different time periods and places in which Protestant denominations and women's liberation movements are interconnected in different ways.

In the case of the IDMJI, I studied how various Protestant denominations expanded from the United States to Latin America and, focusing primarily on Pentecostalism, I tried to understand what it stands for and the position that women have within its teachings and structures. In order to understand the IDMJI itself, I attended several Church meetings, what they call teachings, for over a month every Sunday. I attended these services in one of the IDMJ churches located in Milan, Italy, ${ }^{9}$ which has a male preacher. Although the Church is located in Italy, the majority of its parishioners are Colombians that converted when they were still in Colombia (with a small number that converted once in Italy); others come from other Latin American countries like Peru or El Salvador (some converted in their country of
7. This is a commonly known practice of this political Party in Colombia. One of their members said on a public interview to Semana en Vivo on March 24th, 2018: «El sistema cremallera consiste precisamente en que las listas vayan conformadas por hombre, mujer, hombre de manera alterna... aunque no es una ley nosotros si lo implementamos. Creo que esto ha sido uno de los ejercicios más positivos... actualmente por ejemplo en la Cámara [de Representantes] somos dos mujeres y un hombre, y los electos para Senado son dos mujeres y un hombre, y en la Cámara queda una mujer, que era la que encabezaba la lista». [The zipper system consists precisely in that the lists are formed by man, woman, man alternately ... although it is not a law, we implement it. I think this has been one of the most positive exercises ... currently for example in the House [of Representatives] we are two women and one man, and the elected for Senate are two women and one man, and in the House [of Representatives] there is a woman, who was the head of the list.]. This and any other translation of this material, unless stated otherwise, is mine. Available at: https://www. facebook.com/cablenoticias.tv/videos/ vb.179399815422469/205668602769 3829/?type=2\&theater

8. Unofficial because legally the only recognized groups are the ones that represent the different parties elected.

9. According to the IDMJ website, they have temples all around the word, from Argentina and Australia, to several European countries and the United States. It possible to access their website in Spanish, English, French and Italian. It is possible to see the list of their locations at their website: https://idmji.org/locations/ 
origin and others once in Italy, with a prevalence of the latter); and a small number of Italian parishioners. ${ }^{10}$

I made clear from the beginning that I was there to conduct fieldwork for my Master's dissertation, focused on the relation between women and religion, and I explained that I knew the Church because of my former job at Bogotá's City Council; however, I never stated that I was not an official member of the Church. I did not want to give them the impression that I was a parishioner, but I also did not want them to feel as mere objects of my research. During my visits I entered in conversation with different members of the Church, the pastor and his wife. I also took notes of the sermons and the proceedings, including the testimonies, a moment of the services in which the parishioners tell publicly how God has blessed them and manifested in their lives. I even participated in the ritual of prophecy, in which every person that is new to the Church, i.e., every newcomer, is invited at the end of the meeting to hear from one of the parishioners that has been gifted with the gift of prophecy. This gift refers to the ability to be a spokesperson for God, telling a person God's plan for him/her. The invitation is also extended to Church members but always giving priority to newcomers.

Apart from the participant observation, I carried out a series of semi-structured individual interviews and a discussion group with ten members of the Church, eight women and two men. All the women I interviewed had been blessed with the ability to minister gifts from the Holy Spirit (prophecy, healing and/or laying of hands) and, as such, they hold important roles within the Church. The men were the husbands of two of these women and one of them was an usher. Another source that played an important part in my research was Piraquive's autobiography, called Vivencias. In it, Piraquive does not only tell her life story, but also the history of the IDMJI.

I also followed the official accounts of the Church, the Party, and several of its members on social media, particularly on Facebook, and studied the description that the IDMJI and MIRA do of themselves on their official websites.

Up to this day, Colombia is a predominantly Catholic country. This predominance is due not only to Colombia's Spanish colonial past, where the Catholic Church ruled alongside the Spanish Crown (Levine, 1981; Beltrán, 2013), but also because, for most of its republican life, the Colombian government had an official relation with the Catholic Church (Beltrán, 2013). In 1887 Colombia signed a Concordat with the Vatican, which consolidated the relation between the State and the Catholic Church. This treaty stated that Catholicism was the religion of Colombia and gave the Catholic Church am-
10. Although the common belief is that these 'migrant' Churches only serve their respective migrant communities, Claudia Währisch-Oblau (2009) in her study of Evangelical/Pentecostal Churches from the global south in Germany, recognizes that theses Churches see themselves as missionaries with the duty to spread the true Gospel all around the world. In the IDMJI temple in Milan I saw at least six Italians attending the meetings regularly, and at least one of them gave her testimony during cult on how God had blessed her. The Church in Milan has simultaneous translation systems and has started singing the hymns in Italian.

\section{FROM THE}

CONSECRATION TO

THE SACRED HEART

OF JESUS TO BEING

BLESSED BY THE HOLY SPIRIT 
ple powers to rule over the lives of the Colombian people. In 1902, Bogotá's Archbishop established the rite of formally consecrating the country to the Sacred Heart of Jesus, a rite that was performed annually by the President until the 1990s (Beltrán, 2013).

During the twentieth century, and in spite of the multiple disagreements between the two predominant political parties of the time, the Liberal and the Conservative, the Concordat was always upheld by the different Colombian governments. The conflict between these two political parties came to a climax in 1948 due to the murder of liberal leader Jorge Eliecer Gaitán. It led to an intensified armed conflict between Liberals and Conservatives known as La Violencia (The Violence). In 1953 General Gustavo Rojas Pinilla took power through a coup d'etat and ruled the country until 1957, when the leaders of the different political parties convinced the military government to hold a constitutional plebiscite to end violence. The plebiscite was adopted in 1958 and was known as el Frente Nacional (the National Front). According to both Levine (1981) and Beltrán (2013), the pact had the blessing of the Catholic Church. In turn, the new preamble of the Constitution recognized the predominance of the Catholic Church:

En nombre de Dios, fuente suprema de toda autoridad, y con el fin de afianzar la unidad nacional, una de cuyas bases es el reconocimiento hecho por los partidos políticos de que la Religión Católica, Apostólica y Romana es la de la Nación y que como tal los, poderes públicos la protegerán y harán que sea respetada como, esencial elemento del orden social...

[In the name of God, supreme source of all authority, and in order to strengthen national unity, one of whose bases is the recognition made by the political parties that the Catholic, Apostolic and Roman Religion is that of the Nation and that, as such, public authorities will protect it and will make it respected as an essential element of social order ...]

La Violencia was particularly hard on Colombian Evangelicals since they were severely persecuted and denounced even from the Catholic pulpits. Many Evangelicals were killed, even by police officers and other armed forces, and their churches and schools were destroyed; «the survivors relate stories of stonings, being thrown in jail, hiding out for long periods of time in caves in the mountains, or escaping to the cities» (Brusco 1995, 38; Beltrán 2013). However, and partially because of the persecution during La Violencia, in which the majority of foreign missionaries left the country and people were forced to keep their worshipping hidden, this period and the relative peace that came afterwards saw an explosion of conversion and 
consolidation of Evangelism in Colombia, favouring the creation of independent and new Pentecostal and Evangelic Churches in the country (BrusCo, 1995; Beltrán, 2013).

Pentecostalism was born in the United States in the dawn of the twentieth century. It does not have just one founder, instead its beginnings are traditionally associated with two events: Charles Parham's identification in 1901 of glossolalia (the gift of speaking in tongues) as the definite evidence that the Baptism of the Holy Spirit had occurred, and the Azusa Street Revival that took place in Los Angeles from 1906 to 1909, led by William Joseph Seymour, a black holiness preacher that had been Parham's student in Houston, Texas (Stephenson, 2012). From the Azusa revival, several men and women emerged, after experiencing the Baptism of the Holy Spirit, to preach the message of Pentecostalism (Ibídem). Pentecostalism is also not institutionally defined. There are many Churches in the United States and around the world that consider themselves as Pentecostals or Neo-Pentecostals, but they do not have a centralized power or way of account for membership in the way that, for example, the Catholic Church does (Jacobsen, 2006).

Pentecostalism is based in the promises contained in Acts 2:17-18, where Peter repeats Joel's prophecy:

${ }^{17}$ In the last days, God says, I will pour out my Spirit on all people. Your sons and daughters will prophesy, your young men will see visions, your old men will dream dreams. ${ }^{18}$ Even on my servants, both men and women, I will pour out my Spirit in those days, and they will prophesy.

This means that Pentecostals believe in the Baptism of the Holy Spirit and in those gifts that come with that baptism, such as speaking in tongues, healing and prophecy. They «assume that all of these miraculous powers, and possibly more, are available to Christians today in the same way that the New Testament says they were available to Christians in the first century» (Jacobsen, 2006: 4). This Baptism of the Holy Spirit can happen to both men and women, and in fact some early Pentecostal preachers were women, like Maria Beulah Woodworth-Etter, who helped founding the Assemblies of God; and Aimee Semple McPherson, founder of the International Church of the Foursquare Gospel in 1927 (Jacobsen, 2006; Stephenson, 2012; Payne, 2015).

Nevertheless, Lisa P. Stephenson claims that «the impartial outpouring of the Spirit in Acts 2 has infrequently resulted in an impartial practice of ministry among Pentecostals» (2012: 18). According to her studies, women could participate in the Lord's gifts and in ministry «as long as that work did not include usurping authority over men» (Ibídem: 22). The research conducted by Leah Payne (2015) reinforces Stephenson's conclusions. Even if 
women actually felt what Payne denominates the call, it did not necessarily gave them any authority, in fact «even with a compelling call, female revivalist ministers [including Pentecostals] were often relegated to small churches, prohibited from making doctrine or policy, and absent from positions of power in denominational leadership» (Payne, 2015: 13). The majority, if not all, of the different Pentecostal Churches in the United States systematically excluded women from ministry, they did not ordain them, and they were not allowed to preach. While some have changed their practices from 1970s onwards and now consider that both men and women are able to preach and be called to ministry, others have kept the exclusion of women from ministry and preaching (Stephenson, 2012).

As part of the Evangelical tradition, Pentecostalism expanded around the world and particularly in Latin America, where it arrived as early as the 1930s (Stoll, 1990; Brouwer et. al., 1996). According to Douglas Jacobsen «Pentecostalism is rightly known for its adaptability and innovation in the areas of religious practice, communication technology, cultural assimilation, and organizational structure» (2006: 1). It is this plasticity and adaptability that allows both Stoll (1990) and Beltrán (2013) to claim that in Latin America implant they once were. Pentecostals in Colombia founded and now run their own churches, in which they have included, advertently or inadvertently, elements from popular Catholic religiosity and indigenous religious practices (Beltrán, 2013). By the 1960s there were several autochthonous Evangelical and Pentecostal churches in Colombia, alongside those founded and dependent on foreign denominations (ídem).

Even if Catholicism is still the predominant religion in Colombia, while the majority of Catholics are mainly passive or nominal believers, Pentecostals are what is known as an active religious minority. This means that, while Catholics «express a weak sense of belonging to the Church and have a scarcely participation in institutional religious rituals»"1 (ibídem: 107), Pentecostals have a greater level of commitment to their Churches, which is reflected in a more disciplined attitude towards the guidelines and beliefs of their faiths. This greater commitment has an impact not just on Pentecostals' private lives but also on their political participation. As a result, even a minority of Pentecostals can be «more visible and effective than the Catholic passive majorities» ${ }^{12}$ (ibídem: 108).

Beltrán (2013) and Elizabeth E. Brusco (1995) agree on the fact that there is a numerical preponderance of women in Colombia's Evangelical movement. For Brusco (1995), this predominance is due to the fact that women can hold positions of significance within these religious groups, which in turn means that they can influence the development of the Evangelical/ Pentecostal movement with their particular female perspective. Although

11. Los católicos «expresan un débil sentimiento de pertenencia a su Iglesia y que participan escasamente en rituales religiosos institucionales».

12. «Pueden ser incluso más visibles y efectivas que las mayorías católicas pasivas». 
I do not completely agree with Brusco's conclusions, my own experience with the women of the IDMJ allowed me to witness first-hand that belonging to the church did actually bust their self-esteem and their sense of self-worth.

When it comes to the position of women inside the Church, the predominant practice of Pentecostal churches in Colombia, following the example of the American Churches, has been based on excluding women from ministry, even if they can occupy other positions of lower rank power, like healers or teachers. This practice has begun to change, but the majority of preachers and pastors continue to be men, even if some Christian women affiliated to different denominations have had important roles in the public sphere as politicians (Beltrán, 2013). In this scenario, a Colombian Pentecostal church that is actually led by a woman signifies an interesting ground for research on how women can and actually negotiate their positions within this type of religious structures.

The IDMJI identifies itself as a Neo-Pentecostal Church, and its Statement of Faith declares that «the main spiritual gift from the Holy Spirit that operates in Church is the gift of prophecy, through which God guides people's lives».13 The IDMJI was founded in 1972 by Luis Eduardo Moreno, the late husband of the current leader of the Church, María Luisa Piraquive. According to Piraquive's autobiography (2017), they started the denomination because one night, while they and some friends were praying, God manifested himself through her and gave them the order to establish a new Church as well as the promise that the new denomination would be particularly prosperous.

Throughout her account, Piraquive is adamant in asserting that God gave ministry to both her and her husband, even if Moreno denied it to her. For this reason, it was only until her husband's death in 1996, that women, including her, started preaching in the Church. Before that, women's spiritual duties, including those of Piraquive, were limited to ministering the different gifts, mainly, prophecy and healing. Piraquive refers to women preaching as one of the Holy Spirit revelations to her, «El Espíritu Santo siempre me decía que me estaría respaldando, que yo tenía Ministerio, que Él usaría a las mujeres igual que a los varones y que esto me lo estaría comprobando en un tiempo no muy lejano» ${ }^{14}$ (Piraquive de Moreno, 2017: 100). One of the women I interviewed during my fieldwork, sister Adriana, ${ }^{15}$ mentioned those same promises and told me that the important role that women enjoy today in the IDMJ started when Piraquive took control of the Church,

Recuerdo desde mi niñez que el señor hacía promesas que Él estaría utilizando a la mujer igual. De hecho, hacía promesas muy grandes y
"GODLY PROPHESIES": A COLOMBIAN PENTECOSTAL CHURCH LED BY A WOMAN

13. «Statement of Faith». IDMJl, 2017. Available at: https://idmji.org/historicalprecedents-in-an-international-context/2/

14. «The Holy Spirit always told me that He was supporting me, that I had a Ministry, that He would use women as well as men and that this would be proven in a not too distant time». This and any other translation of this material, unless stated otherwise, is mine.

15. The names of all the people interviewed have been changed in order to keep their anonymity. 
eso se ha venido cumpliendo muchos años después. 20 años después. Digamos que la partida de lo que en verdad es el rol de la mujer en la iglesia lo podría decir que fue a partir de que Dios le da las riendas a la hermana María Luisa, con la partida del hermano Luis. Ese es el momento en que Dios ya materializa esas promesas que había hecho y ella ha sido el primer ejemplo de ese rol de la mujer en la iglesia, que es igual que el hombre. ${ }^{16}$

[I remember from my childhood that the Lord promised that He would be using woman in the same manner as man. In fact, He made very big promises that came true many years later. 20 years later. Let's say that the starting point of what is really the role of women in the Church, I could say, it was from the moment God gave Sister Maria Luisa the reins, with the departure of Brother Luis. That is the moment in which God materialized the promises He had made, and she has been the first example of that role of the woman in the church, which is the same as that of a man]

The IDMJI justifies this change affirming that doctrine can be dynamic because it can change if the Holy Spirit reveals it. In this way, Carlos Eduardo Baena, the main preacher after Piraquive, explains in the prologue to Vivencias the different practices into which the doctrine has evolved, including the possibility of having female preachers,

Frente a la mujer y la predicación, se tiene por misterio que el Espíritu Santo no le aclaró en vida al Hermano Luis, lo que hoy gozamos. Entendía que ellas le hablarían a las personas acerca de Dios, pero no subirían al pulpito. Más adelante, es decir, después de su partida, el Señor entró a aclarar las cosas al respecto, demostrando una vez más que podemos partir hacia la eternidad sin entender muchas cosas; con la Hermana María Luisa se abrió la posibilidad para que la mujer predique en la Iglesia, porque así se lo reveló el Espíritu Santo y hay algunas hermanas que ya lo han hecho en la iglesia. En este sentido, la Hermana María Luisa es pionera, recorriendo un camino que privaba a la mujer de cualquier posibilidad. Ahora estamos en presencia de las predicadoras, que con su testimonio y con su enseñanza, enriquecen la Iglesia del Señor (Baena López, 2017: XX-XXI).

[Regarding woman and preaching, it is considered a mystery that the Holy Spirit did not make clear to Brother Luis in life, what we enjoy today. He understood that they [women] would speak to people about God, but they would not go up to the pulpit. Later, that is to say, after his departure, the Lord came to clarify things about it, demonstrating once again that we can leave for eternity without understanding

16. All the interviews were made in Spanish. Their translation in English is mine. 
many things; with Sister Maria Luisa the possibility was opened for women to preach in the Church, because it was revealed to her by the Holy Spirit and there are some sisters who have already done so in the Church. In this sense, Sister Maria Luisa is a pioneer, following a path that deprived women of any possibility. Now we are in the presence of the female preachers, who, with their testimony and their teachings, enrich the Church of the Lord]. ${ }^{17}$

Believing that doctrine can change with time can be seen as what Daphne Hampson identifies with the Kairos approach, according to which God is involved in history in a way that God creates the appropriate situation for new realities, such as, precisely, women preaching. This approach «allows it to be said that the past has not been at fault; it is simply that God moves with humanity into a new age» (Hampson, 1990: 23). The Kairos approach is consistent with a religious practice like Pentecostalism, which believes that God still manifests in this age by different means. The IDMJI gives particular importance to the ways God manifests in people's lives. Their Statement of Faith declares that «God manifests Himself to Church through prophecy, visions, and dreams $\rangle^{18}$ and one of the sermons I attended was precisely focused on understanding that God speaks in a particular way. The sermon was called "¿Qué significa me lo revelaste al oído?», ${ }_{1}^{19}$ and according to the preacher, based on several biblical passages, the only way God reveals himself is through prophecy that can be written, that is, the Bible, or spoken, as told by a prophet of the Church; or in the form of dreams or visions. Although God can manifest to anyone, when it comes down to what is the proper doctrine of the Church, this can only be determined by the one invested by God with Ministry. In the case of the IDMJI, this refers to Moreno and, after his death, Piraquive. As such, as stated before, women had to wait until Moreno's death and Piraquive's leadership to be able to hold, at least in theory, all the authoritative roles the IDMJI has to offer them.

Vivencias reflects the disagreements Piraquive had with her husband on this matter. There is one particular incident in which Moreno actually tells Piraquive that she has no ministry and that the Church is going to get rid of her after his death, a reason for which he forbade her outright to speak or teach in the Church. Piraquive explains these instances as attacks from the devil, who was using her husband's jealousy against her, and turns the situation in her favor describing how God told her to be patient because He would be heightening her position in the Church. Church members remember these times and Sister Adriana, who has been a member of IDMJ since childhood, told me:

Era una iglesia que venía de una tradición donde el hombre es el que predica, el hombre es el que lleva a cargo. De hecho, el señor
17. This and any other translation of this material, unless stated otherwise, is mine.

18. «Statement of Faith», op. cit.

19. «What does it mean You revealed it to my ear?». The translation is mine. 
me permitió estar en ese tiempo y conocer al esposo de la hermana María Luisa, al hermano Luis. La hermana a pesar de que tenía la misma responsabilidad, ella nunca, nunca lo dio a conocer, porque en ese momento era todo enfocado en el hombre.

[It was a church that came from a tradition where the man is the one who preaches, the man is the one who is in charge. In fact, the Lord allowed me to live that time and meet the husband of Sister Maria Luisa, Brother Luis. The Sister, even though she had the same responsibility, never, never made it known, because at that time it was all focused on the man].

By casting her husband decision of denying her Ministry as an attack of the devil, affirming that the Holy Spirit told her «El diablo está usando a tu esposo, porque quiere destruir la iglesia, tu hogar y tu vida spiritual» 20 (Piraquive de Moreno, 2017: 110-111), Piraquive is able to remove the focus from her husband's attitudes, justifying his behaviour not in a shortcoming on his part, but on temptations and actions beyond his sphere of control. Furthermore, she also reinforces her allegedly close relation to God: it is the Lord who gave her the strength to patiently bear these attacks from the devil, who was using her husband's weaknesses to undermine her. Hence, Piraquive was able to actually reinforce and not weaken the call that gave her prophetic authority. If God continued to call her to His service, even when her husband, the original leader of the church, told her not to preach, it was because He actually wanted her as His maidservant. Thus, her autobiography can also be read as an instrument to prove and justify her Ministry, focusing precisely on the instances where God called on her, and the obstacles she had to overcome in order to obey His word.

Nevertheless, Piraquive also makes sure to underline how she never abandoned the role of dutiful wife and mother, performing it happily and selflessly. Piraquive describes how she found joy in everyday tasks like cooking and cleaning. She does not complain about the fact that she could not finish her studies or find a job, because her husband did not allow her to do it, instead claiming that it was God who ordered her to study, «porque a la iglesia llegarán personas importantes y estudiadas a fin de que al hablar con ellas no te sientas acomplejada» ${ }^{21}$ (Piraquive de Moreno, 2017: 68). She also declares that it was God who gave her the time and financial resources to study and that it was Him who found her a job. Piraquive portrays herself as a self-denying wife, one that resignedly waited in God's time and patiently endured her husband's mistreatments because she knew that it was the work of the devil. The moral of the story seems to be that, for all Piraquive's services, patience, abnegation and obedience, God rewarded her and turned her into the «worldwide leader of the Church of God Ministry of Jesus Christ International».22
20. «The devil is using you husband because he wants to destroy the Church, your home and your spiritual life».

21. «Because important and studied people will come to the church so that you do not feel self-conscious when talking with them».

22. According to the description the Church's official website makes of her: https://idmji.org/en/ 
All the women I interviewed saw Piraquive's leadership as an example, and called onto the fact that God had revealed to her that women and men were meant to fulfil the same duties as a source of strength that allowed them to realize their own potential. Sister Doris told me that,

Y el valor que dan aquí a la mujer. Porque el valor que hay aquí es incalculable. Porque muchas veces existe el machismo ¿no?, pero vemos aquí que el valor de la mujer es muy indispensable, y que aquí Dios tiene trabajando a la mujer y que la líder de este templo es una mujer, donde tiene el respaldo y donde aquí nos sentimos amadas, respetadas y que nuestra opinión cuenta mucho. Y que la mayoría de las personas aquí que le sirven a Dios son mujeres. Donde Dios a muchas les ha dado un hogar, a muchas que no podían tener hijos los tienen. Muchas que no estaban trabajando Dios les ha dado... Muchas que no tenían títulos de estudio ahora se están preparando, donde están estudiando... las mujeres nos sentimos privilegiadas.

[And the value that they give woman here. Because the value that we have here is incalculable. Because there is often machismo, right? But we see here that the value of women is very indispensable, and that here God has women working and that the leader of this temple is a woman, where she is supported and where we feel loved, respected and that our opinion counts a lot. Most of the people here who serve God are women. Where God has given many of them a home, many who could not have children now have them. Many who were not working have been given [a job] by God. Many who did not have qualifications are now preparing, they are studying... women feel privileged].

And in the same direction, Sister Clara said that the Church taught her how to value herself,

[La Iglesia] me ha enseñado a valorarme, a saber que uno tiene un valor... que uno cuenta... Me ha enseñado a no sentirme menos, a no sentirme nunca discriminada... He llegado a sentir ese apoyo de poder decir"si soy capaz de llevar un hogar. si soy capaz de ser esposa, de ser madre. Si soy capaz de trabajar. Si soy capaz de estudiar". Y llevar todo contemporáneamente, no olvidándome quien soy... Ahora se que todos los retos que pueda emprender puedo lograrlos. Y con Él yo puedo ser un super-humano, una super-mujer.

[[The Church] has taught me to value myself, to know that one has a value... that one counts... It has taught me not to feel inferior, to never feel discriminated against... I have come to feel that support of being 
able to say «yes, I am capable of running a home. Yes, I am capable of being wife, of being a mother. I am able to work. I am able to study». And carry everything at the same time, not forgetting who I am... Now I know that all the challenges I undertake can be achieved. And with Him I can be a super-human, a super-woman].

For her part, Sister Beatriz recognized that being in this Church has given her value and has allowed her to recognize good characteristic in herself,

El Señor ha comenzado a darme el valor de mujer ¿no? Porque a pesar de que yo tengo niños y de que, como dicen lo más bonito, lo más hermoso que uno puede dar es dar vida ¿no? Pero no sentía el valor que el Señor le empieza a dar, a reconocer a uno. Que uno tiene cualidades que el Señor va sacando y uno va maravillándose que había algunas cosas buenas en uno. Y yo me siento muy feliz, y muy dichosa y muy contenta. Y le agradezco tanto al Señor por haber permitido conocerlo. [The Lord has begun to give me the value of a woman, right? Because, even though I have children and that, as they say, this is the most beautiful thing, the greatest thing that one can give is to give life, right? But I did not feel the courage that the Lord started to give me [here], to believe in myself. That one has qualities that the Lord brings to the forefront and one marvels that there were some good things inside oneself. And I feel very happy, and very joyful and very pleased]

All of these women's experiences and stories were spoken from an inner feeling of being people that matter and whose goals are accomplishable because God is with them; the same God who told them that women have the same value as men. In the words of Sister Adriana,

el hecho de que sea yo como mujer importante para Dios y que tenga el mismo valor y que pueda hacer lo mismo [que un hombre], por supuesto que me da un empoderamiento, y pienso que es algo que Dios hace con la autoestima de uno, y que le da esa fuerza, no para sentirse superior, como digo, sino en igualdad de condiciones.

[The fact that I, as a woman, am important to God and that I have the same value and can do the same [as a man], obviously makes me feel empowered, and I think that it is something that God does with one's self-esteem, and that gives one the strength to not feel superior but equal].

Therefore, being in the Church has enhanced these women's self-esteem, by giving them a positive sense of value that in turn provides them 
with the strength to accomplish their goals. These assertions coincide with the observations made by Olga Lucía Rey Martínez, as cited by Beltrán (2013), during her fieldwork with Evangelical and Pentecostal women in Bogotá's poor neighborhoods. This is not only a personal change, it also involves their families, and in particular their husbands. Of the women I interviewed, two of them were married before converting to the IDMJI and now they and their husbands are part of the Church. Both Sister Doris and Sister Miriam recounted that their husbands and their interpersonal relationships had changed for the better. Sister Miriam's husband, Brother Hernando, recognizes that he has changed since coming to the Church, and that he is less short-tempered as well as more patient and understanding with his wife. Hence, the assertion that men and women can serve God in exactly the same way seem to have impacted their lives in positive ways. What these testimonies reveal is that women that belong to the IDMJ feel empowered by the idea that they can be the Lord's handmaidens with the same authority, responsibilities and burdens that men have. This does not only have significance within the Church but also, by enhancing their confidence and self-esteem, gives them strength to act in other areas of their lives like the academic and professional ones. This is not to say that everything is positive. The IDMJ keeps gender stereotypes pretty much untouched, and the value of women is still highly related to their role, actual or virtual, as wives and mothers.

Even if the IDMJ states that men and women can equally fulfil the different authoritative positions available in the denomination, the reality is that men, including the current president of the Political Party, hold the most important roles after Piraquive. In addition, most preachers are still men. The new doctrine is there, the practice is not. Moreover, the fieldwork allowed me to experience first-hand the roles that the IDMJI considers proper for men and women. The idea that men and women complement each other perfectly was repetitive during the sermons and the interviews. The positive side of this statement is that in a relationship men and women sustain each other, as sister Clara put it, «donde yo no puedo, él puede, donde él no puede, yo puedo, y nos apoyamos». ${ }^{23}$

However, this has a negative side. Firstly, although they claim that men and women are equal in marriage, they also maintain the idea of man as the head of the household. This implies a hierarchy between husband and wife, in which he rules as head and she is submited. Ideally, the woman submits herself willingly, but this keeps her in a practical and symbolic secondary position. Secondly, by presenting man and woman as complementary, the IDMJ excludes other kinds of relations apart from the heterosexual one. In her autobiography, Piraquive (2017) refers to homosexuality and lesbianism as a sin. She actually recalls an episode in which a preacher was expelled from the Church after preaching that God authorized homosexuality and lesbianism. Because
23. «Where I can't he can, and where he can't I can, we support each other». 
she and the Church have faced legal charges for discriminating against members of the LGBTQ+ community, Piraquive affirms, «la Iglesia sabe que a nadie

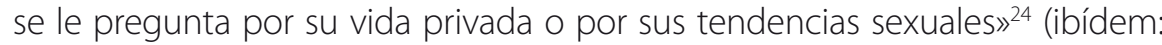
163), and declares that it is God who has changed the deviant tendencies of gays and lesbians that have joined the Church,

Recuerdo el caso de una joven que le dijo a la Iglesia que ella estaba en el lesbianismo y así permaneció en la Iglesia durante unos años, hasta que de un momento a otro se le fue perdiendo esa tendencia sin ella tener que hacer nada extraordinario, y que después en profecía el Espíritu Santo le dijo que le iba a dar un esposo y ella efectivamente se había casado con un hombre que le había llenado de felicidad la vida. Así es como se trabaja en la Iglesia, es Dios quien trabaja, no yo, no las amenazas, ni la imposición humana (ibídem: 173).

[l remember the case of a young woman who told the Church that she was a lesbian and remained like that in the Church for a few years, until at a certain moment that tendency was lost without her having to do anything extraordinary, and that later in prophecy the Holy Spirit told her that He was going to give her a husband and she actually married a man who filled her life with happiness. This is how the Church's works, it is God who does the work, not me, not threats or human imposition]

This approach to the LGBTQ+ community is dangerous, negative and disheartening for several reasons. It is dangerous for LGBTQ+ individuals that belong to the Church because they are being forced, if not threatened, by peer pressure and authoritarian calls, to resignedly hide their true selves and accept heterosexual relationships, to the detriment of their emotional and psychological health. It is negative for society at large, because members of the IDMJ have political power, either as constituents when casting their votes or as representatives when holding public office. In fact, the official statutes of the Church's Political Party declare in article 6.1.f, «La familia: principio de la sociedad. El Partido Político MIRA protege como célula fundamental de la sociedad a la familia; entiende, además, el matrimonio como el vínculo entre un hombre $y$ una mujer» ${ }^{25}$ Therefore, they stand as an actual threat to the rights that the LGBTQ+ community has fought so hard to obtain.

But the IDMJI does not only champion heterosexual relations and the role of the wife, it also sees motherhood as an essential part of being a woman. During the discussion group, when I asked them to explain how they would define women, both men and women referred to woman as being 'the vessel of life' and 'the one that gives life'. During the individual interviews, the possibility of being a mother or actually being one was a
24. «The Church knows not to ask anybody about his or her private life or his or her sexual tendency».

25. «The family: the principle of society. MIRA protects the family as the fundamental cell of society; understands, moreover, marriage as the link between a man and a woman». This and any other translation of this material, unless stated otherwise, is mine. MIRA. 2016. Estatutos. Available at: https://partidomira.com/wpcontent/uploads/2018/07/Estatutos.pdf 
prevalent characteristic. While there is nothing wrong with valuing motherhood, putting it as the pinnacle of a woman's life is problematic. Firstly, it relegates women that cannot be or do not want to be mothers to a secondary position, because they are not fulfilling their social purpose. Secondly, it affects negatively the exercise of women's sexual and reproductive rights, because practices like abortion are seen as a sin. During the discussion group, their position was that giving life was women's gift and that aborting was a murder and a way of denying that gift. If what matters the most is the 'new life' that is being formed, once a woman gets pregnant, she loses every right to self-determination and bodily autonomy. In a country like Colombia, where abortion is legal only in three instances, and only because the Constitutional Court declared it was unconstitutional to criminalize abortion in every case, ${ }^{26}$ a position like this jeopardizes the chances women have to decide about their own body.

All these stereotypes and prejudices have the real potentiality of reaching the realm of public policy because, as stated before, the Church has its own Political Party: MIRA. The party was co-founded by Alexandra Moreno Piraquive, Piraquive's oldest daughter, and Carlos Alberto Baena López, the main preacher of IDMJI after Piraquive. Originally Alexandra Moreno Piraquive was its president, and she won a seat in the Senate for three consecutive terms (2002-2014). In 2014 Moreno Piraquive left the Party and since then the Party has been presided by men, first by Carlos Alberto Baena and now by Carlos Eduardo Guevara.

Beltrán (2013) citing Reyes, affirms that MIRA is the main political force with a Pentecostal base in Colombia and that its constituents have gone beyond the parishioners of the IDMJI. MIRA has had a nationalization strategy, arriving to even the remotest regions of Colombia and participating in every level of political circumscriptions: Juntas Administradoras Locales- JAL, City and Municipal Councils, Departmental Assemblies and the National Congress (Reyes cited by Beltrán 2013; Ortega Gómez 2014). MIRA is the only political party in Colombia that has used the zipper system to set up their electoral lists, which guarantees equal participation between men and women. Some of their most prominent members are women. Some examples are Gloria Stella Diaz, who has served as a member of the House of Representative for Bogotá for two consecutive terms, as a council member in Bogotá and as a Senator; and Ana Paola Agudelo, who served as a member of the House of Representatives for Colombians abroad and now serves as Senator.

The Party has focused its efforts on presenting or supporting bills in favor of women, children and the elderly (Beltrán 2013), such as the bill that condemns the acid attacks on women or the law that typifies feminicide as a crime. ${ }^{27}$ The Party also defends women in special conditions of oppression, like community mothers (madres comunitarias). ${ }^{28}$ In 2011, MIRA supported the
26. The instances are pregnancy product of rape, danger for the life or health of the mother and unfeasibility of the fetus. See Sentencia C-355 de 2006. M.P. Jaime Araújo rentería y Clara Inés Vargas Hernandez.

27. «MIRA pide Unidad Especializada de la Fiscalía para atender víctimas de ataques con ácido y feminicidio». MIRA, August 4th, 2016. Available at: https://partidomira. com/mira-pide-unidad-especializada-lafiscalia-atender-victimas-ataques-acidofeminicidio/

«MIRA solicita al Gobierno Nacional decretar alerta naranja por feminicidios en el país». MIRA. June 3rd, 2017. Available at: https://partidomira.com/mira-solicitaal-gobierno-nacional-decretar-alertanaranja-feminicidios-pais/

28. Community mothers are women that the State put in charge of taking care of children in poor and marginalized neighbourhoods and zones all around Colombia, without paying them or recognizing their activities as a job. «Defensa de las madres comunitarias por parte de Irma Luz Herrera, representante por el MIRA a la Cámara de Representantes por Bogotá». August 23rd, 2018 Available at: https:// www.facebook.com//rmaLuzHerrera/ videos/1875434459214588/ 
Antidiscrimination Bill (Beltrán, 2013), which became Ley 1482 de 2011,29 and which created new criminal types that condemned discrimination based on race, ethnicity, religion, sex or sexual orientation, among others. MIRA was also one of the parties that promoted the peace agreements, ${ }^{30}$ which means that the IDMJ was one of the few Christian Churches that supported the agreements.

Nevertheless, the tides seem to be changing. During the 2018 presidential campaign MIRA decided to openly support the candidate of Uribismo, Iván Duque, ${ }^{31}$ and thus made an alliance with Centro Democrático, a right-wing party and the main opposer to the peace agreements. During the congressional debates regarding the Especial Jurisdiction for Peace (Jurisdicción Especial para la Paz - JEP), MIRA decided to abandon the debate and not support the corresponding bill because, according to its then-president, the gender perspective included in the agreements could only mean men and women, and should not refer to the LGBTQ+ community or people's sexual orientation or gender expression. ${ }^{32}$ This is a change of strategy from 2011 when MIRA supported the antidiscrimination Act, even if it criminalizes discrimination based on sexual orientation. This may also mean that MIRA intends to take a much more active approach when it comes to opposing the rights of the LGBTQ+ community as well as the sexual and reproductive rights of women. Consequently, although the IDMJI and its political party can give women some instruments for their empowerment, they also maintain several gender stereotypes, particularly when it comes to the sexual and reproductive aspects of life, which reinforce the patriarchal society and keep the members of traditionally oppressed groups in a secondary and degraded position.

\section{BIBLIOGRAPHY}

Baena López, Carlos Alberto (2017). «Prólogo a Vivencias». En María Luisa Piraquive de Moreno (2017). Vivencias. Bogotá: Iglesia de Dios Ministerial de Jesuscristo Internacional. Librería y Papelería Futuro Ltda, vii-xxxi.

Beltrán, William Mauricio (2013). Del monopolio católico a la explosión pentecostal: pluralización religiosa, secularización y cambio social en Colombia. Bogotá: Universidad Nacional de Colombia. Centro de Estudios Sociales (CES).

Brouwer, Steve, GifFord, Paul and Rose, Susan D. (1996). Exporting the American Gospel: Global Christian Fundamentalism. Ebook edition. New York: Routledge.

Brusco, Elizabeth E. (1995). The Reformation of Machismo: Evangelical Conversion and Gender in Colombia. Austin: University of Texas Press.
29. The text of the Law can be found in this: https://www.funcionpublica.gov.co/ eva/gestornormativo/norma.php?i=44932

30. «Este 2 de octubre de 2016, MIRA vota "SÍ" en el Plebiscito». MIRA. September 26th, 2016. Available at: https://www. youtube.com/watch? $\mathrm{v}=9 \mathrm{ai} 39 \mathrm{~V} y \mathrm{rs} T \mathrm{k}$

31. «Partido MIRA anuncia acuerdo programático con candidato presidencial Iván Duque». MIRA. May 10th, 2018. Available at: https://partidomira. com/partido-mira-anuncia-acuerdoprogramatico-con-candidato-presidencialivan-duque/

32. «MIRA pide cumplir Enfoque de Género establecido en los Acuerdos de Paz». MIRA. May 22nd, 2018. Available at: https://partidomira.com/mira-pidecumplir-enfoque-de-genero-establecidoen-los-acuerdos-de-paz/

«En el debate a la reglamentación de la Justicia Especial para la Paz, el Senador Carlos Alberto Baena López pidió respetar el Enfoque de Género establecido en el Acuerdo Final de Paz». MIRA. May 22nd, 2018. Available at: https://www.facebook. com/watch/?v=10156441377983777 
Hampson, Daphne (1990). Theology and Feminism. Oxford: Basil Blackwell.

JACOBSEN, Douglas (2006). A Reader in Pentecostal Theology: Voices from the First Generation. Bloomington and Indianapolis: Indiana University Press.

LEVINE, Daniel H (1981). Religion and Politics in Latin America. The Catholic Church in Venezuela and Colombia. Princeton, New Jersey: Princeton University Press.

Ortega Gómez, Bibiana Astrid (2014). «De Movimiento Religioso a Partido Político: el caso del Movimiento Independiente de Renovación Absoluta - MIRA». Gestão e Desenvolvimento (11/2), 1-23.

PAYNE, Leah (2015). Gender and Pentecostal Revivalism. Making a Female Ministry in the Early Twentieth Century. New York: Palgrave Macmillan.
Piraquive de Moreno, María Luisa (2017). Vivencias. Cuarta edición. Bogotá: Iglesia de Dios Ministerial de Jesuscristo Internacional. Librería y Papelería Futuro Ltda

Stephenson, Lisa P. (2012). Dismantling the Dualisms for American Pentecostal Women in Ministry: Dismantling the Dualisms for American Pentecostal Women in Ministry. Leiden and Boston: Brill.

Stoll, David (1990). Is Latin America Turning Protestant? The Politics of Evangelical Growth. Berkeley: University of California Press.

Währisch-Oblau, Claudia (2009). The Missionary Self-Perception of Pentecostal/ Charismatic Church Leaders from the Global South in Europe: Bringing Back the Gospel. Leiden and Boston: Brill. 